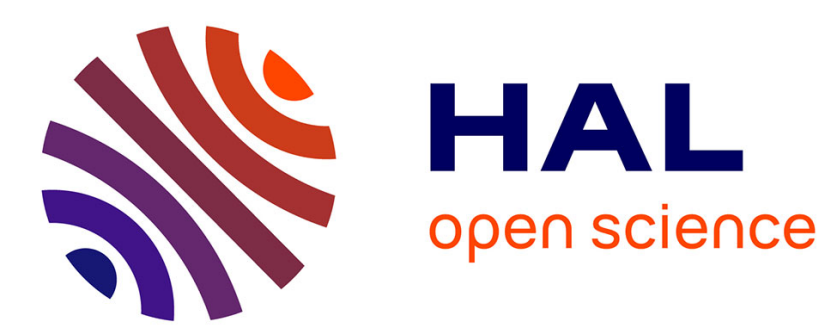

\title{
Preparation, characterization, and decay of einsteinium(II) in the solid state
}

J. Peterson, D. Ensor, R. Fellows, R. Haire, J. Young

\section{To cite this version:}

J. Peterson, D. Ensor, R. Fellows, R. Haire, J. Young. Preparation, characterization, and decay of einsteinium(II) in the solid state. Journal de Physique Colloques, 1979, 40 (C4), pp.C4-111-C4-113. 10.1051/jphyscol:1979435 . jpa-00218831

\section{HAL Id: jpa-00218831 https://hal.science/jpa-00218831}

Submitted on 1 Jan 1979

HAL is a multi-disciplinary open access archive for the deposit and dissemination of scientific research documents, whether they are published or not. The documents may come from teaching and research institutions in France or abroad, or from public or private research centers.
L'archive ouverte pluridisciplinaire HAL, est destinée au dépôt et à la diffusion de documents scientifiques de niveau recherche, publiés ou non, émanant des établissements d'enseignement et de recherche français ou étrangers, des laboratoires publics ou privés. 


\title{
Preparation, characterization, and decay of einsteinium(II) in the solid state $(*)$
}

\author{
J. R. Peterson, D. D. Ensor, R. L. Fellows $(* *)$, R. G. Haire $(\dagger)$ and J. P. Young $\left(^{* * *}\right)(\dagger)$ \\ Department of Chemistry, University of Tennessee, Knoxville, TN 37916 and Transuranium Research Laboratory, Oak \\ Ridge National Laboratory, Oak Ridge, TN 37830, U.S.A. \\ (†) Transuranium Research Laboratory, Oak Ridge National Laboratory, Oak Ridge, TN 37830, U.S.A.
}

\begin{abstract}
Résumé. - Pour la première fois, des échantillons de $\mathrm{EsCl}_{2}, \mathrm{EsBr}_{2}$ et $\mathrm{EsI}_{2}$ ont été préparés par réduction des trihalogénures d'einsteinium correspondants par de l'hydrogène à des températures élevées. Les trois dihalogénures ont été caractérisés principalement par leurs spectres d'absorption. Les produits de décroissance d'échantillons de $\mathrm{EsX}_{2}$ maintenus à la température ambiante et à la température de l'hélium liquide ont été suivis par spectrophotométrie. Dans tous les cas, l'identification positive des espèces petit-fils, Cf $\mathrm{X}_{2}$, a été faite. Aucune preuve spectrale définitive de la présence possible du produit fils $\mathrm{BkX}_{2}$ n'a été obtenue.

Abstract. - Samples of $\mathrm{EsCl}_{2}, \mathrm{EsBr}_{2}$, and $\mathrm{EsI}_{2}$ have been prepared for the first time by reduction of the corresponding einsteinium trihalides with hydrogen gas at elevated temperatures. The three dihalides were characterized primarily by their absorption spectra. The products of the decay of Es $\mathrm{X}_{2}$ samples held at ambient and liquid helium temperatures have been monitored by spectrophotometry. In all cases positive identification of the granddaughter, $\mathrm{CfX}_{2}$, species has been made. No definite spectral evidence for the presence of the possible daughter products, $\mathrm{BkX}_{2}$, has been obtained.
\end{abstract}

1. Introduction. - Two factors severely limit the study of einsteinium chemistry in the solid state : (1) only several hundred micrograms of einsteinium become available twice a year ; and (2) the intense radiation associated with the decay of the predominant isotope Es-253 $\left(9.3 \times 10^{8} \mathrm{dis} / \mathrm{s} \cdot \mu \mathrm{g}\right.$; $2.5 \times 10^{2} \mathrm{~kJ} / \mathrm{mol} \cdot \mathrm{s}$ ). Both factors require that special microchemical techniques be used in such studies, and the second factor precludes the routine use of X-ray powder diffraction for the analysis of bulk phase einsteinium compounds.

Although the existence of Es(II) has been anticipated for some time [1-3] and actually demonstrated in two, tracer-level experiments $[4,5]$, the preparation of a bulk phase compound of Es(II) has been achieved only recently [6]. Since $\mathrm{CfCl}_{2}$ [7], $\mathrm{CfBr}_{2}[8]$, and $\mathrm{CfI}_{2}$ [9] were prepared by hydrogen reduction of the corresponding trihalides, we expected that the corresponding Es(II) halides could be prepared in an analogous way. We report here the preparation of $\mathrm{EsCl}_{2}, \mathrm{EsBr}_{2}$, and $\mathrm{EsI}_{2}$, their characteristic absorption spectra, and the results of monitoring the products formed by the radioactive decay process

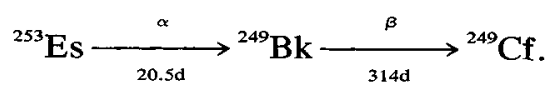

(*) Research sponsored by the Division of Nuclear Sciences, U.S. Department of Energy under contracts EY-76-S-05-4447 with the University of Tennessee (Knoxville) and W-7405-eng-26 with Union Carbide Corporation.

(**) Present address : Chemical Technology Division, ORNL.

(****) Analytical Chemistry Division, ORNL.
2. Experimental. - A complete summary of the microscale preparative and spectrophotometric techniques employed in the present work is available in $[10]$ and the references therein. The reactions $2 \mathrm{EsX}_{3(\mathrm{~s})}+\mathrm{H}_{2(\mathrm{~g})} \rightarrow 2 \mathrm{EsX}_{2(\mathrm{~s})}+2 \mathrm{HX}_{(\mathrm{g})}$ were carried out by repetitive treatments for $15-20$ minutes with $\mathrm{H}_{2}$ at temperatures in excess of $575{ }^{\circ} \mathrm{C}, 750{ }^{\circ} \mathrm{C}$, and $800{ }^{\circ} \mathrm{C}$, respectively, for the successively heavier halides, with intervening evacuations to remove HX. At any stage of the synthesis we could transfer [10] the sample-capillary unit (closed with a stopcock) to a microscope-spectrophotometer for analysis of the sample composition. Adjustment of the conditions of subsequent $\mathrm{H}_{2}$ treatment could then be made, if necessary, to ensure essentially complete reduction to $\mathrm{EsX}_{2}$.

For monitoring the sample composition as a function of time, the sample capillary was flame sealed under reduced pressure of $\mathrm{H}_{2}$ or Ar. Samples to be stored in liquid $\mathrm{He}$ were further encapsulated in a glass tube inside a copper tube before immersion. These samples were removed from the liquid $\mathrm{He}$ prior to spectral analysis. In all cases spectral data were obtained at ambient temperature without annealing the sample and then again immediately following several minutes' annealing at $\sim 435^{\circ} \mathrm{C}$. The latter treatment generally yields spectral data of higher resolution than that obtained without annealing. However, the annealing process itself might effect a chemical change in the sample.

3. Results and discussion. - Spectra of $\mathrm{EsCl}_{2}$, $\mathrm{EsBr}_{2}$, and $\mathrm{EsI}_{2}$ are presented in figure 1. A spec- 


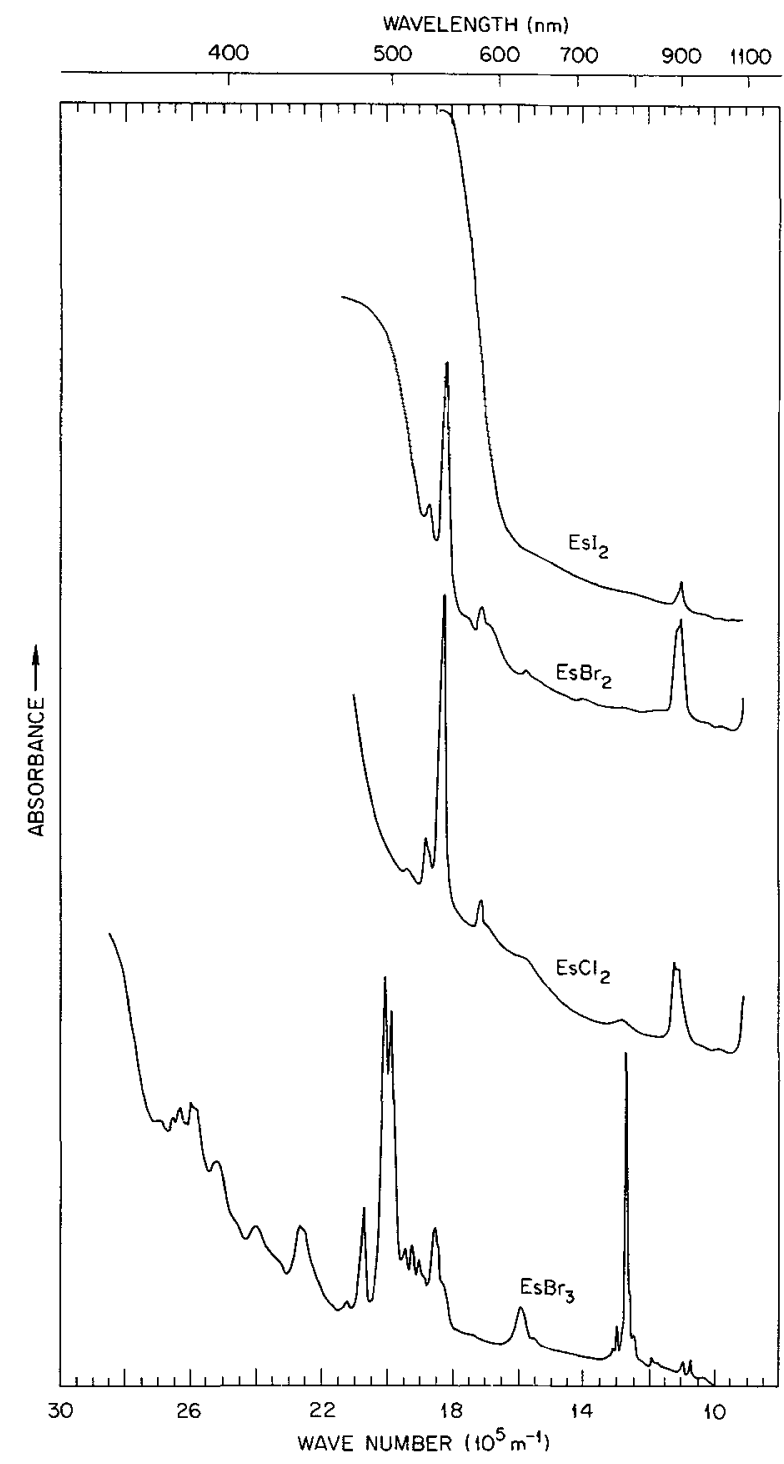

Fig. 1. - Absorption spectra of $\mathrm{EsCl}_{2}, \mathrm{EsBr}_{2}, \mathrm{EsI}_{2}$ and $\mathrm{EsBr}_{3}$.

trum of $\mathrm{EsBr}_{3}[11]$ is included for comparison. The dihalide absorption peak positions as well as the UV cutoffs shift to lower energy with the heavier halides. Some of the f-f absorption peaks of Es(II) are similar to those of $\mathrm{Cf}(\mathrm{II})[7,9]$, a fact which compli- cates the interpretation of spectral data obtained from aged $\mathrm{EsX}_{2}$ samples.

The reversibility of the

$$
2 \mathrm{EsX}_{3}+\mathrm{H}_{2}=2 \mathrm{EsX}_{2}+2 \mathrm{HX}
$$

reactions has been demonstrated. We determined through repetitive cycles of chemical synthesis/spectral analysis that high temperature (at or above the melting point of $\mathrm{EsX}_{3}$ ) is required for complete reduction. Low-temperature reduction may lead only to mixed-valence compounds [12].

An interesting feature of our research has been the study of the chemical species that result from the radioactive decay of $\mathrm{EsX}_{2}$ compounds. Is $\mathrm{BkX}_{2}$, unknown in bulk phase, produced through the alpha decay of $\mathrm{EsX}_{2}$ ? Or more generally, are chemical oxidation states maintained through alpha and beta decay processes ? Samples of the three einsteinium dihalides (and one each of (Es, $\mathrm{Yb}) \mathrm{Cl}_{2}$ and $\mathrm{Es}(\mathrm{II})$ in $\mathrm{LaCl}_{3}$ ) sealed in $\mathrm{H}_{2}$ and stored at ambient temperature have been under study for various lengths of time. A sample of $\mathrm{EsCl}_{2}$, sealed in $\mathrm{Ar}$ and stored at ambient temperature, is under study as a companion sample to the above to test the influence of the sample's atmosphere. A sample of $\mathrm{EsBr}_{2}$ sealed in $\mathrm{H}_{2}$ was stored for 200 days in liquid $\mathrm{He}$ to minimize sample self-annealing.

Common to all the aged EsX $\mathrm{X}_{2}$ samples analysed so far is the presence of the corresponding granddaughter $\mathrm{CfX}_{2}$ species and the absence of new absorption peaks which might be attributed to $\mathrm{BkX}_{2}$ species. One might speculate that since the parent and granddaughter species have been identified as dihalides, the intermediate, daughter species should also be a dihalide.

In two, aged samples of $\mathrm{EsBr}_{2}$, limited $(<5 \%)$ oxidation to the (III) state occurred, producing $\mathrm{CfBr}_{3}$ in the sample stored at ambient temperature but producing $\mathrm{CfOBr}$ in the sample stored in liquid $\mathrm{He}$. This result, which suggests the occurrence of different chemistry at the different temperatures, awaits confirmation. Continued study of the effects of time, storage temperature, and sample atmosphere on the chemical consequences of the radioactive decay of $\mathrm{EsX}_{2}$ is planned or presently underway.

\section{References}

[1] MaLÝ, J., J. Inorg. Nucl. Chem. 31 (1969) 1007.

[2] Nugent, L. J., Baybarz, R. D., BuRnett, J. L. and Ryan, J. L., J. Phys. Chem. 77 (1973) 1528 and the references therein.

[3] David, F., Samhoun, K., Guillaumont, R. and Edelstein, N., J. Inorg. Nucl. Chem. 40 (1978) 69 and the references therein.

[4] Edelstein, N., Conway, J. G., Fujtta, D., Kolbe, W. and MClaughlin, R., J. Chem. Phys. 52 (1970) 6425.
[5] Mikhéev, N. B., SprTsyn, V. I., KamenSkaya, A. N., RoSENKEVITCH, N. A., RUMER, I. A. and AUERMAN, L. N., Inorg. Nucl. Chem. Lett. 8 (1972) 869.

[6] Fellows, R. L., Peterson, J. R., Young, J. P. and Haire, R. G., The Rare Earths in Modern Science and Technology, McCarthy, G. J. and Rhyne, J. J. Editors (Plenum Press, New York) 1978, p. 493.

[7] Peterson, J. R., Fellows, R. L., Young, J. P. and Haire, R. G., Radiochem. Radioanal. Lett. 31 (1977) 277. 
[8] Peterson, J. R. and Baybarz, R. D., Inorg. Nucl. Chem. Lett. 8 (1972) 423.

[9] Wild, J. F., Hulet, E. K., Lougheed, R. W., Hayes, W. N., Peterson, J. R., Fellows, R. L. and Young, J. P., J. Inorg. Nucl. Chem. 40 (1978) 811.

[10] Young, J. P., Haire, R. G., Fellows, R. L. and PETERSon, J. R., J. Radioanal. Chem. 43 (1978) 477.
[11] Fellows, R. L., Peterson, J. R., Nó́, M., Young, J. P. and HaIre, R. G., Inorg. Nucl. Chem. Lett. 11 (1975) 737.

[12] Haire, R. G., Young, J. P., Peterson, J. R. and Fellows, R. L., The Rare Earths in Modern Science and Technology, McCarthy, G. J. and Rhyne, J. J. Editors (Plenum Press, New York) 1978, p. 501 , and the references therein. 